\title{
CONSERVING MODERATE ISLAM IN INDONESIA An Analysis of Muwafiq's Speech on Online Media
}

\author{
Mohamad Salik | UIN Sunan Ampel Surabaya - Indonesia \\ mohamadsalik1212@gmail.com
}

\begin{abstract}
This study aimed to examine the ideas of one prominent Nahdlatul Ulama (NU) preacher named KH Ahmad Muwafiq (Muwafiq) about Islamic moderation in Indonesia while preaching in Bogor Palace on November 21, 2018. Through content analysis of Muwafiq's preaching that was uploaded on YouTube media, this study found that there are two main themes in Muwafiq' speech that were seemed related to the efforts to conserve moderate Islam; first is his preaching model has emulated the Prophet Muhammad model in proselytising Islam, such as wise, non-violent, and adjustable to the character and condition of the society. The second is related to the influence of tradition and culture in the implementation of Islamic teachings.
\end{abstract}

Keywords: Moderate Islam, Nahdlatul Ulama, content analysis, proselytising model

\section{Introduction}

Indonesia is a country with a high level of diversity in terms of culture, ethnicity, nation, religion, language and so forth. The Indonesia's diversity is a wealth for people's lives on the one hand, but it becomes a threat of nation on the other hand. It means that the Indonesian people should recognize and be able to accept the differences amongst them. Without such awareness, nationalism that has been built so far will be ruined by conflict and separatist movements.

Since the democratic freedom was opened in 1998, the Indonesian people began to be disturbed by radical issues which had been able to be muffled by the previous governments. This issue has strengthened since the last decade, especially after the Taliban victory in Afghanistan, the tragedy of September 11, 2002, and the ISIS 
movement in Syria and Iraq. Islamic movements often carry the ideology of jihad, Islamic law, Islamic state, and Islamic caliphate. ${ }^{1}$ Issues relatedto race and ethnicity have also emerged from within the country, which have occurred in several regions in Indonesia, such as inter-ethnic conflict in Sambas Central Kalimantan, conflicts of religious issues in Poso, Central Sulawesi, in Ambon Maluku, Aceh separatist movements and finally is a case of ethnic disputes in Papua that has yet to be resolved. ${ }^{2}$

In order to overcome the problems, various efforts have been made both by the government and community organizations through promoting the ideas of religious moderation. According to Luqman Hakim Syaifudin, ${ }^{3}$ moderation is a joint commitment to maintain balance in a heterogeneous society, ranging from ethnic, national, religious, cultural and political differences, so that everyone can hear, learn from, and understand one another regarding these differences, in order to maintain the unity and integrity of the nation.

This paper is in-depth analysis of how the ideas of religious moderation delivered by one of the NU clerics, namely $\mathrm{KH}$ Ahmad Muwafiq well-known as Muwafiq in the commemoration of the Prophet's Birthday at the Bogor Palace on 22 November 2018. ${ }^{4}$

\section{The Roots of Moderate Islam in Indonesia}

Literally, the term "moderation" comes from the English word which means the quality of being moderate, freedom from excess (quality being moderate, free from excessive). 5 The term "moderation" implies a position which is not excessive, not too soft and not too rigid, so taking a middle position, can be accepted by reason. Khaled el

1 Zuhairi Misrawi, "Dialektika Islamisme, Khilafah, dan Syariat," Komaruddin Hidayat (ed.), Kontroversi Khilafab: Islam, Negara, dan Pancasila (Bandung: Mizan, 2014), pp. 69-71.

2 Aryo Bhawono, "Isu Separatisme Papua tak Akan Picu Konflik Indonesia Australia," https://news.detik.com/berita/d-3937373/isu-separatisme-papua-tak-akan-picu-

konflik-indonesia-australia, accessed on 31 October 2019.

3 Lukman Hakim Saifuddin, "Sambutan Menteri Agama Republik Indonesia," Kementerian Agama RI, Moderai Beragama (Jakarta Pusat: Badan Litbang dan Diklat Kementerian Agama RI, 2019), pp. v-vi.

${ }^{4}$ Ahmad Muwafiq, "Gus Muwafiq Jelaskan Al Fatikhah dan Kafir di Istana Bogor

" https://www.youtube.com/watch?v=W11LQhgDPrs, accessed on 1 November 2019.

5 As. Hornby, Oxford Advanced Dictionary of Current English (Great Britain: Oxford University Press, 1987), p. 544. 
Fadl in his book The Great Theft as quoted by Zuhairi Musrawi explains that moderation is a concept that takes the middle path of two paths, neither leaning to the right nor to the left. ${ }^{6}$ The term "moderation" is often equated with the term al-Wasathiyah in Arabic, which means trying to take the middle position, compromising between two opposing ideas in a position that is equally acceptable to reason, not to hurt one another. ${ }^{7}$

Substantively, the Indonesian people have strong foundation related to the experience of moderation culturally, socially and religiously. The Indonesian people have become accustomed to living in harmony, peace, tolerance, maintaining brotherhood and mutual respect for differences in the midst of a pluralistic society. Besides, as a religious community, the Indonesian people uphold religious teachings and human values to respect one another. ${ }^{8}$

In the midst of a peaceful society, Islam came to the archipelago by Walisongo (the 9 well-known Islamic saints who initially spread Islam in Indonesia) that provided examples of how to preach politely, friendly, and tolerant to the community, so as to attract the interest of the community to follow the teachings of Islam with pleasure and without coercion. From that success, the Walisongo can be seen as a reliable architecture for the entry of Islam into the archipelago.

There were many superiorities of the strategy used by the Walisongo in spreading Islam. Among of the superiorities lied in their ability to integrate religious aspects with secular aspects. It was so enthralling the way of preaching of the Walisongo, that Islam taught to the people was deeply rooted even as if Islam became the Religion of Java. ${ }^{9}$ Meanwhile, according to Amin Haedari, the superiority factor of the Walisongo so they achieved great success in preaching Islam in the archipelago was their ability to incorporate the values of Islamic teachings through the culture that had developed in the archipelago. In

6 Zuhairi Misrawi, Hadratussyaikh Hasyim Asy ari Moderasi, Keutamaan dan Kebangsaan (Jakarta: PT Kompas Media Nusantara, 2010), p. 13.

7 Kementerian Agama RI. Moderasi Beragama (Jakarta Pusat: Badan Litbang dan Diklat Kementerian Agama RI, 2019), p. 16. See also, Masdar Hilmy, "Whither Indonesia`s Islamic Moderatism? A Reexamination on the Moderate Vision of Muhammadiyah and NU," Journal of Indonesian Islam, 7, 1 (June 2013), p. 26.

8 Said Agil Husin Al Munawar, Fiqh Hubungan Antar Agama (Ciputat: Ciputat Press, 2005), p. 16. See also Kementerian Agama RI. Moderasi Beragama, p. 9.

${ }_{9}$ Koentjaraningrat, Kebudayaan Jawa (Jakarta: Balai Pustaka, 1994), p. 312. 
the preaching there was no reason for Arabization inherent in it, on the contrary, the Walisongo were very tolerant and even able to use the culture or traditions that exist in the local community as means to carry out their $d a^{\prime} w a$ (invitation to Islam). They did not defeat the culture or tradition for the sake of preaching, but tried to reconcile the teachings of religion and tradition instead, so that between the two there was no defeat. ${ }^{10}$

\section{NU and the Ideas of Moderate Islam}

$\mathrm{NU}$ is considered as one of the Islamic organizations the bearer of moderate ideas as it adopts Abl al-sunnah wa al-Jama'ab which is classified as a moderate school. Literally, Abl al-Sunnah wa al-Jama'ah means adherents or followers of the Sunna of the Prophet Muhammad SAW and his companions. ${ }^{11}$ The characteristics of this school are; 1) in the field of creed, it follows the ideals spearheaded by Abul Hasan al-Ash'ari and Abu Mansur al-Maturidi. 2) In the field of Jurisprudence or Islamic law, it follows one of the four madhabs, namely Imam Hanafi, Imam Maliki, Imam Shafi'i, and Imam Hanbali. 3) In the field of Sufism, it follows the teachings brought by al-Junaid al-Baghdadi and Imam Al-Ghazali. ${ }^{12}$

The school of Abl al-Sunnab which is a hallmark of the NU is basically seen as a middle ground for understanding at the time. In the field of theology, the views of Abul Hasan al Asy ari and Abu Mansur Al-Maturidi came to be seen as a reaction to the thought of Mu itarila that gives greater portions to the powers of the intellect, and to the understanding of the Jabariya that does not give any favor to the strength of human endeavors. In the field of Jurisprudence, the understanding of the four schools followed by the NU especially the Imam Shafi $i$ is known by some Muslim scholars to be the most moderate of all the earlier schools. Even the NU community's acceptance of legal products from the school Imam is also not absolute. There is still a forum that examines and revisits the law

\footnotetext{
10 Amin Haedari et al., Masa Depan Pesantren dalam Tantangan Modernitas dan Tantangan Kompleksitas Global (Jakarta: IRD Press, 2004), pp. 224-225.

11 Zamakhsari Dhofier, Tradisi Pesantren; Studi tentang Pandangan Hidup Kyai (Jakarta: LP3ES), p. 148.

12 Ahmad Zahro, Tradisi Intelektual NU: Lajnah Babtsul Masa ¿il 1926-1999 (Yogyakarta: LKiS, 2004), p. 19.
} 
before becoming a guideline, known as bahtsul masail. Further the NU also embraces the Sufism as the basis for moral formation. ${ }^{13}$

These religious traditions ultimately form the characters among the NU. These characters are used as the basis for normative social attitudes of this organization, they include: 1) tawasuth and itidal, namely the middle and straight attitude, upholding the necessity of being fair and being proportional in the community and not being extreme, 2) tasamuh, which is a tolerant attitude towards differences in views, both regarding religious issues, society, politics, culture and so on, 3) tawazun, which is a balanced attitude in all matters, both related to the relationship to God, to fellow human beings, and also balanced in relation to the environment. 4) Amar ma 'ruf nabi munkar, invites good and beneficial things and prevents despicable things, which can damage and undermine the dignity and values of human life. ${ }^{14}$

The four basic social attitudes adopted by the NU above, then shape their behavior and color their daily life patterns, both related to individual and social life and political attitudes. In the field of politics, for example, this organization fights for Pancasila as the basis of the state and the Unitary Republic of Indonesia as the final form of the state. ${ }^{15}$ Concerning the term "jihad", the NU circles mean that jihad no longer necessarily means war. War is necessary when we are attacked by the enemy, more than that, jihad can have a broader meaning. In the current context, jihad can mean working hard to get better conditions, such as fighting against ignorance, poverty, corruption, and so forth. In short, jihad covers all aspects of life; in the field of economy, social, politics, law. education and so on. ${ }^{16}$

The above characters of NU are then developed in the lives of Indonesian people so that they have moderate attitudes amid plural and multicultural national life. The government, in this case the Indonesian Ministry of Religion, in a book entitled "Moderasi Beragama" emphasizes the importance of maintaining balance in religious

13 Kacung Marijan, Quo Vadis NU Setelah Kembali ke Khittab 1926 (Jakarta: Penerbit Erlangga, 1992), pp. 22-25.

14 Ahmad Zahro, Tradisi intelektual NU, p 24. See too, Kacung Marijan, Quo Vadis NU, p. 26.

15 KH. Husein Muhammad, "Pesantren, NU dan Islam Nusantara", Abi Attabi", Antologi Islam Nusantara (Yogyakarta: Aswaja Pressindo, 2015), p. 14.

16 Muhammad Chirzin, "Reaktualisasi Jihad fi Sabilillah dalam Konteks Kekinian dan Keindonesiaan," Ulumuna 10, 1 (2006), p. 71. 
practices, namely by taking a middle ground and not being extreme. ${ }^{17}$ In another part of the book also emphasizes the importance of the Indonesian people to have attitudes that reflect the characters of moderation, among others; 1) having a high national commitment 2) tolerance and mutual respect for one another 3) non-violence, and 4) accommodating the local cultures. ${ }^{18}$

To strengthen the commitment of moderation, lately NU has also come up with an idea known as "Islam Nusantara."19 This idea is raised, one of which is to prevent radical movements and terrorism that have recently been rife in various parts of the world lately, including in Indonesia. According to Akhmad Sahal, Islam Nusantara is a way of life of Muslims in the archipelago at the present time by applying Islamic teachings as a whole, respecting the local cultural contexts and the spirit to put the values of benefit in it. ${ }^{20}$ According to KH Ma ruf Amin, there are five characteristics of the Islam Nusantara; islabiyyah (reform), tawazuniyyah (balance), tatawwu'iyyah (voluntary), akblaqiyyah (polite), tasamub (tolerant). ${ }^{21}$

\section{The Phenomenon of Muwafiq's Ngaji Online}

Muwafiq is one of the NU figures living in Mlati Sleman Yogyakarta. When studying at IAIN Yogyakarta, he became an activist and served as Secretary General of Islamic Students in Southeast Asia. When Abdurrahman Wahid was a President, he became one of his personal assistants. ${ }^{22}$

As a Muslim Scholar, Muwafiq has a broad understanding of the fields of religion, politics, and history. He is known to have very strong memorization relating to the genealogy of science, theories of the creation of man, and the universe, the history of the Prophets and how

17 Kementerian Agama RI, Moderasi Beragama, p. 18.

18 Ibid., p. 42.

19 This idea was officially launched at the $33^{\text {rd }} \mathrm{NU}$ conference in Jombang East Java in August 2015.

20 Akhmad Sahal, "Kenapa Islam nusantarta?” Ahmad Sahal and Munawir Aziz (eds), Islam Nusantara dari Ushul Fiqh hingga Pabam Kebanagsaan (Bandung: Mizan Pustaka, 2016), p. 30.

21 KH. Ma'ruf Amin, “Khittah Islam Nusantara,” Kompas, 29 August 2015.

22 Ahmad Naufal KF, "Siapa Gus Muwafiq? Ini 5 hal penting Kiai Berambut Gondrong," https://bangkitmedia.com/siapa-gus-muwafiq-ini-5-hal-penting-kiai-berambut-gondrong/, accessed on 18 November 2019. 
Islam is propagated to all over the world. He is also known as a shady preacher, inspiring, relaxed and humorous. Consequently, he is often invited to give speeches to various regions of Indonesia and also abroad. ${ }^{23}$

This section presents the speeches delivered by Muwafiq from various different contexts which were uploaded through YouTube online media. In this case the writer does not take all of his speeches but only four of them which are considered to be representative.

First is Muwafiq's speech delivered at the MPR RI (Indonesian house of representative) building in anniversary of the People`s Consultative Assembly of the Republic of Indonesia and the 74th Anniversary of Indonesia's Independence. The speech is then uploaded through YouTube on August 30, 2019, and up to now has been viewed by 1.707 .763 .000 viewers. ${ }^{24}$ The speech was about the importance of maintaining the integrity of the nation. The essence of the speech is that the existence of the Unitary State of the Republic of Indonesia (NKRI) is not obtained easily way, but must be redeemed with blood and lives. Through the struggles, the founders of this nation succeeded in uniting this nation with the diversity of ethnic groups and religions, and finally the Indonesian state was established and Pancasila becomes its symbol. The choice of the term "People's Consultative Assembly" for this institution is a great momentum and monument for national unity. People's Consultative Assembly is a name chosen by the founder of the nation on the awareness that we have dozens of nations, ethnicities, different religions, races and choose to become a unitary state of the Republic of Indonesia. This did not come suddenly but was an achievement that had been prepared by the founders of the nation in the belief that all the children of this nation must unite.

Second, Muwafiq's speech was delivered at Brawijaya University on November 3, 2019, with the title "Islamic Dialectics and Nationality". The speech was then uploaded via YouTube and until now has been viewed by 710.893 viewers. ${ }^{25}$ The core of the speech is about the

23 Ibid.

24 Ahmad Muwafiq, "Gus Muwafiq Singgung Habib Riziq dan Kafir di Gedung MPR RI, https://www.youtube.com/watch?v=zjh2M1eYI-I, accessed on 1 December 2019.

25 Ahmad Muwafiq, "Live Gus Muwafiq di Unibraw: Tafsir Kontekstual Resolusi Ji had untuk Keilmuan dan Peradaban https://www.youtube.com/watch?v=f2jyRF1g4Ew\&t=1943s, accessed on 1 December 2019. 
importance of strengthening the spirit of nationalism in the millennial era. According to Muwafiq, millennial means cross-border; crossborder knowledge and cross-cultural boundary. At this time humans can reach anything, anytime and anywhere without anyone who can block it. But there is one thing that cannot be broken by millennial people, namely territorial boundaries. Wherever someone goes outside their territorial area will always be asked about their passport identity. That territorial boundary is called the boundary of the nation state that God has given to humanity. The Prophet Muhammad was the only Prophet who received the national message, because when the Prophet was sent to be a Prophet, his people had reached across borders, tribes and nations spread throughout the world. ${ }^{26}$

Third, Muwafiq's speech delivered at the Corruption Eradication Commission (KPK) building on November 20, 2019 during the program of Ngaji Kebangsaan (Religious Speech of Nationality). The speech was then uploaded via YouTube and until now has 94.560 viewers. ${ }^{27}$ The core of the lecture emphasized the importance of caring for the nation's heritage. According to Muwafiq, the Indonesian people have the uniqueness that many other nations do not have. The uniqueness is both natural and the results of the creation of the ancestors of the predecessors. The nature that is associated with natural conditions, consisting of thousands of islands, diverse tribes, with a very beautiful atmosphere and scenery. Uniqueness relates to the creations of the nation's children is in the form of a large variety of languages, arts, traditions and culture.

When Islam came, this nation had become a very strong and civilized nation. In historical records, this nation had conquered twothirds of the world and had conquered the Mongols who had conquered Europeans and the Middle East. This all happened because they had the slogan Bbinneka Tunggal Ika which means Unity in Diversity. Therefore, as Indonesians we must be able to take care of it. The assets of the Indonesian people must not be hidden but must be exposed otherwise because they will become a new force. Because according to Samuel Huntington in his theory of class civilization, only a nation that has indigenous people, indigenous culture and local

\footnotetext{
26 See Q.S. Al Hujarat: 13.

27 Ahmad Muwafiq, "Ceramah Gus Muwafiq: KPK Ikhtiar Anti Korupsi," https://www.youtube.com/watch?v=x7_Xq6zyKS0, accessed on 1 December 2019.
} 
indigenous people will survive the conflict, and the Indonesian people have them all.

Fourth, Muwafiq's speech at Year End Program at Pesantren Darussalam Kediri East Java. The speech was then uploaded via YouTube and until now has 71,296 viewers. ${ }^{28}$ The theme of the lecture deals with the role of pesantren in efforts to maintain diversity. According to Muwafiq, the key to maintaining diversity, is not to keep looking for points of difference, but rather to find points of equality. In a family, husband and wife are two different types, but bound by one thing in common, that is mutual need. The issue of men and women must come first because it is the root of human problems related to efforts to maintain diversity. Pesantren is one form of the educational institutions that is recognized as being able to teach about diversity. Pesantren educates students to become kaffah (perfect) humans, meaning that they are not only experts in terms of knowledge but are also able to practice their values. Judging from its form and content, pesantren is a merging of two elements, viewed from the side of the institution originating from Java, while from the knowledge studied comes from Arabic, namely Islamic teachings brought by Prophet Muhammad Saw. Pesantren educates students to be clever in the religious field, through ways that are adapted to the local character through the guidance of the Muslim scholars. Thus, the model of education in pesantren has indirectly taught life in diversity.

From the description, it can be said that the themes of speech delivered by Muwafiq, in general, are related to 1) efforts to preserve the integrity of the nation, 2) the importance of strengthening nationalism in the millennium era, 3) the importance of preserving heritage race, 4) the role of pesantren in maintaining the unity in diversity.

The above themes are very much relevant to convey in an effort to maintain the moderation of Islam in Indonesia, it can even be said to be the main themes in an effort to build a moderate character. As mentioned in the book entitled "Moderasi Beragama (Religious Moderation)," 29 that moderate attitude can be seen from several indicators. First, national commitment, which is about one's loyalty to

28 Ahmad Muwafiq, "Live Gus Muwafiq: Cara Paling Ampuh Menangkal Islam Ra dikal di Zaman Melenial https://www.youtube.com/watch?v=P98hON2Ohgk, accessed on 1 December 2019.

29 Kementerian Agama RI, Moderasi Beragama, p. 43. 
the existence of the unitary state of the Republic of Indonesia (NKRI) and Pancasila as its sole principle. Second, tolerance, which is the ability to respect one another in diversity. Third, non-violence, which does not impose it in the name of difference, but must uphold human values. The fourth is accommodating to local culture.

Muwafiq's has different characteristic with other proselytisers, the difference lies in the nationalist messages that are always delivered in each of his speeches. For this reason, people often refer to speeches delivered by Muwafiq with the term Ngaji Kebangsaan.

\section{Islamic Moderation of Muwafiq's Speech}

In this section Muwafiq's speechin the commemoration of the Prophet Muhammad's Birthday on November 21, 2018 in the context of helping to maintain Islamic moderation in Indonesia is discussed. This speech has the most viewers compared tohis other speeches with 4.813.423 viewers. ${ }^{30}$

Through content analysis, the writer found many expressions used by Muwafiq to describe his views on Islamic moderation. The first is the term rahmatan li al alamin, this term is expressed twice, when he explained about the reach of the Prophet Muhammad in preaching and when he explained about the only concept that is able to overshadow the existence of diversity on this earth, namely the concept of rabmatan li al alamin. Second is the term "non-violent". This term was expressed twice, when he described the method of propagating Islam carried out by the Prophet and when he explained the state of the entry of Islamic teachings into the archipelago, namely in a non-violent way. Third is the term "Ahl al sunnab wa al jama 'ab". This term is expressed twice, when he explained about how the Prophet gave guidelines to humans to follow the teachings of the Prophet and when describing how Muslims in Indonesia can understand the teachings of the Prophet while the distance is very far, namely by following the sunnah of the Prophet through the Muslim scholars called Abl al sunnab wa al Jamaah. The fourth is "tolerant". This term was expressed once as he explained the concept of living together, namely with deliberation in which contained the values of tolerance.

30 Ahmad Muwafiq, "Gus Muwafiq Jelaskan Al Fatikhah dan Kafir di Istana Bogor ," https://www.youtube.com/watch?v=W11LQhgDPrs, accessed on 1 November 2019. 
In line with those terms denoting the importance of religious moderation, Muwafiq stated at the beginning of his preaching thatthe reach of the preaching of the Prophet Muhammad was very broad even the widest of all previous prophets. The preaching of the Prophet Adam is only limited to one familyand to one nation, while the scope of the preaching of the Prophet Muhammad includes the entire universe. He stated:

"The Prophet Adam took care of one family, namely his wife, Qobil and Habil, it was in itself, complicated for Adam. Then Noah was sent as messenger for one community, while Ibrahim for one nation, it had also been very complicated. After that, it was Muhammad who was assigned to take care all of the nature or as rahmatan li al alamin.' 31

The statement shows that the duties and responsibilities of the Prophet Muhammad were very wide and even the widest compared to the other Prophets. He became a Prophet when mankind had grown up in numbers, tribes, and nations. Therefore, the concept of religious teachings he brought reached all over the world and mercy for all nature called rabmatan li al alamin.

The term "rahmat" literally means love. Islam as rahmatan li al alamin means that Islam is a religion that spreads love for the whole world. The Quraish shihab as quoted by Abudin Nata explains that being a blessing is not only his teaching, but the Prophet Muhammad as his bearer is also a mercy to the whole world. 32 Nur Syam further explained that with the coming of the Prophet Muhammad and the teachings he brought, it would provide salvation not only to Muslims, but to all humanity and all that exists in this universe. In his terms, what are saved are habl min Allah, habl min al nas and habl min al alam. ${ }^{33}$ It shows that Islamic teachings are moderate. When the concept of rabmatan li al-alamin is implemented in Indonesia, there will be a tolerant, humanist and pluralist Islamic building as it is able to maintain balance in life among people with nature and to the Lord.

31 Ibid.

32 Abudin Nata, Islam Rahmatan Lil Alamin sebagai Model Pendidikan Islam Memasuki Asean Community, http://abuddin.lec.uinjkt.ac.id/articles/islam-rahmatan-lil-alaminsebagai-model-pendidikan-islam-memasuki-asean-community, accessed on 27 November 2019.

33 Nur Syam, Merumuskan Islam Rabmatan Lil Alamin, http://nursyam.uinsby.ac.id/?p=514, accessed on 27 November 2019. 
In his speech, Muwafiq also discussed about why Muhammad was born in Mecca. In his opinion, the traces of all the Prophets starting from Prophet Adam to the Prophet Muhammad were around Mecca. The arrival of Muhammad as the last Prophet was born in Mecca to rediscover prophetic symbols and explain the connection between the Prophet Muhammad and the previous Prophets. In this case he stated:

"Because Mecca was the initial guidance of humans to know God, there was built the oldest monument as a sign that humans must return to God. When humans moved around the guidance was lost, then God sent Abraham to look for it, and finally Abraham rediscovered the guidance, then Prophet Abraham rebuilt the site. After the guidance was lost, the next prophet was sent, Moses, carrying the Torah for the Jews, and the Gospel to the next prophet, Jesus, who was means for Christians. Then Allah showed back to the initial path with the birth of the Prophet in the city of Mecca." ${ }^{34}$

This statement shows that God always sends religion to every people. This means that the need for religion is a nature for every human being. As stated by Farid Esaac that religious phenomenon is universal and inclusive, where every human being has an instinct for religion. ${ }^{35}$ To meet these needs, God sent a messenger (rasul) to each people to give directions to the right path. As stated in the Qur'an:

"And every people have apostles, then when their apostles have come, a decision is made between them fairly and they (not the least) are persecuted." (QS Yunus: 47). In another verse: "Indeed, We revealed to you (Muhammad) just as We revealed to Noab and the prophets afterwards, and we revealed (again) to Abraham, Ishmael, Isaac, Ya'qub and his grandcbildren, Jesus, Ayub, Jonah, Aaron and Solomon, and we give David the Psalm." (QS An-Nisa : 163).

The two verses above show the justice of God for all people. It means that all human beings have the same opportunity to get guidance from God through his apostles and that also proves the recognition of Islam for the truth of the teachings of the Prophet previously derived from God. This is proof of the universality of

\footnotetext{
34 Muwafiq, “ Gus Muwafiq Jelaskan.

35 Farid Esaac, Qur'an Literaty and Pluralism: an Islamic Perspective of Inter Religious Against Oppression (Oxford: Oneword Publication, 1997), p. 146.
} 
Islamic teachings and at the same time is a form of the strict attitude of Islam in accepting the reality of religious pluralism.

As the last Prophet, Muhammad is seen as the most successful Prophet in carrying out the mission propagating Islamic teaching. In this case, Muwafiq explained that the key of his success lies in his ability to adjust the methods of preaching following the conditions and character of the community. As he explains: "The Messenger of Allah (may peace be upon him) taught there in the style of the people there, he was known as non-violent, not rude, but would hope that this people would return to Allah." 36

The ability of the Prophet to preach in a way that is gentle, not rude, and his ability to win the hearts of his people was the key to his success in his mission of preaching. So that the actual teachings were very difficult to be accepted by the community at that time, they could be well received. In this case Muwafiq gave an example: "Arabs worshiped God manifested in the form of statues, but in Islam there is no such statue manifestation, There, people were taught the existence many gods, but Islam only teaches one God, in Arabic there were no water, whereas Islam teaches ritual washing using water. In Arab the weather is hot, but Islam teaches people to fast. ${ }^{37}$

From the examples above shows that Muhammad had been able to make radical changes to the beliefs and character of the Arab nation, and the people gladly accepted the teachings of the Prophet, something that seemed impossible. The main key is the ability to adjust the way of preaching in accordance with the character of society.

What the Prophet did in his da'wa was a clear example of the concept of religious moderation desired in Indonesia. According to the Indonesian Ministry of Religion, ${ }^{38}$ there are two basic principles in religious moderation, the first is fair and balanced, Fair and balanced means to position two things equally; between rights and obligations, between individual interests and shared interests, between religious texts and ijtihad, between ideality and reality. The second principle is balance. This term is to describe the perspective or commitment to always stand for justice, humanity, and equality. Someone who has a balance does not mean they are weak, they will be firm in their actions,

\footnotetext{
36 Muwafiq, "Gus Muwafiq Jelaskan.

37 Ibid.

38 Kementerian Agama RI, Moderasi Beragama, pp. 19-20.
} 
but that firmness does not take away the rights of other people's lives. Similar opinion is stated by Nasaruddin Umar that the attitudes of the Prophet Muhammad in his da wa has given a good example of how to preach wisely; He never forced anyone to convert to Islam, recognized and acted tolerantly to the differences, appreciated human rights and gender equality, gave place to democracy and Appreciated all creatures. ${ }^{39}$ These are all moderate attitudes which have been exemplified by the prophet in preaching.

The development of Islam cannot be separated from tradition. Many local cultures and traditions influence how one practices the teachings of Islam, conversely many Islamic teachings also influence the traditions of the local community. The custom of building a mosque with a tower done by Muslims is one of the examples of how traditions influence the practice of Islam teaching. In this regard Muwafiq explained;

"Persians are the firefighters, then they convert to Islam, the Zoroastrians put the fires in manaro (tower) in their worshiping, when the Persians enter Islam, the fire is extinguished, the manaro is placed in front of the mosque. Then people afterwards competed in building manaro in their mosques. and then Indonesia people called it as menara. ${ }^{40}$

The example above shows that Islam actually develops in a very flexible way in society. Between Islam and traditions that exist in society can go hand in hand and sometimes they also influence each other. Related to this, Quraish Shihab explained, that the long journey of spreading Islamic teachings to various parts of the world including Indonesia met with local customs and culture. In this case the attitudes of Islam are divided into three, namely: First, sometime Islam rejects the culture prevailing in the local community. Second, sometimes Islam accepts the culture prevailing in the local community, but revises it in part. Third, sometimes Islam approves of existing culture without giving any revision. ${ }^{41}$

39 Nasaruddin Umar, "Kisah Masjid nabi dan 7 ciri Islam Moderat", https://m.suara.com/wawancara/2016/06/20/070000/nazaruddin-umar-kisah-masjid-nabi-dan-7-ciriislam-moderat?page=all, accessed on 13 October 2019.

40 Muwafiq, "Gus Muwafiq Jelaskan.

41 Fathurrahman Karyadi, "Islam Nusantara dan Quraish Shihab," Abi Attabi, Antologi Islam Nusantara di Mata, Kyai, Habib, Santri dan Akademisi (Yogyakarta: Aswaja Pressindo, 2015), p. 44. 
Based on the description above, it can be explained that Islam itself does not reject all prevailing cultures and traditions in society, nor does it accept all traditions that exist, but chooses which of these traditions are in accordance with Islamic teachings. It is in line with the view of $A$ bl al sunnah wa al-Jama'ah which emphasizes the need to maintain good traditions in the effort to preserve the authenticity of Islam that originated from the Messenger of Allah and the need to connect religious traditions in the time of the Prophet with subsequent periods according to their respective contexts.

The flexibility of this Islam teaching that ultimately make this religion able to develop into various parts of the world to the archipelago which is spread by the Muslim scholars. So it is natural that the face of Islam adopted by Muslims in Indonesia is not exactly the same as that carried out by the Prophet. This is because the distance is too far and we get knowledge about Islam not directly from the Messenger of Allah but through the Muslim scholars. So that these teachings do not deviate then the Prophet gave a benchmark called $A b l$ al sunnah wa al Jamaah. In this case, Muwafiq stated:

"This is finally an explanation of how we follow the teachings of the Prophet in this place, so far later the Messenger of Allah gave them a direction called abl al sunnab wa al jama ab. The wa al jama ah of Rasulullah was his companions, and the wa al jama'ah of the companion was tabi in and so forth and then came us, we are the generation of Ulamas." ${ }^{42}$

It is clear that the causes of the differences in the application of Islamic teachings between the period of the Messenger of Allah and the present that is applied in Indonesia, none other than because of the distance of space and time, and we are not directly followers of the Prophet but through the Muslim scholars. Additionally, the influence of local conditions, traditions and culture are also important factors in the implementation of Islamic teachings. In this case, Muwafiq explained:

"In Arab, eating uses three fingers, because what is eaten is bread and dates, but in Indonesia, the staple food is no longer bread and dates but people here eat soto, so they cannot eat using three fingers. In Arab, Muslims perform qurban (the sacrifice) - the sacrifice uses camels, here the camels are not born, but goat and

42 Muwafiq, "Gus Muwafiq Jelaskan. 
cow. So the sacrifice uses goat and cow. In Arab, people use beards, but here beards do not grow because we are Mongolian." ${ }^{\$ 3}$

Based on this desciption, in conducting proselytising (da'wa), Muslims do not need to force others to practice religious practices exactly as the Prophet did as the situation, conditions, and culture in Arab are different from those in Indonesia. That is why the Muslim scholars who came to Indonesia never questioned symbols that could not be done by the Indonesian people, this was because the situation and conditions were different.

Indeed true that the teachings of Islam came down to earth not in a vacuum, but it is in a space where humanity has lived with different conditions, traditions, and cultures. So it is a necessity that the teachings of Islam in its development undergo adjustments. This is in line with what was stated by KH Hasyim Muzadi that the history of Islamic development which had lasted no less than fourteen centuries had occupied a variety of space and time which then had a complex shape as it is today, certainly in each phase has its own unique historical background and history. ${ }^{44}$

Major changes occurred when Islam came to the archipelago. When Islam came, the archipelago was already very advanced and civilized, so it was very difficult for Islam to spread. At that time around the year 1220 this nation had had such great strength that this nation had conquered the Mongols, a nation that had conquered Europeans, and the Middle East. Further, this nation also has extraordinary relics. In the field of arts this nation is not inferior to other nations. In this case Muwafiq exemplified:

"Arabs have musical instruments made of wood and leather, Europeans have musical instruments made of wood and ropes, Nusantara people have musical instruments made of metal, namely gamelan. Only a nation that has advanced mining knowledge and an established mastery of metallurgy can make metal instruments." ${ }^{\prime 45}$

In the field of language and literature, this nation is also not inferior to other nations. In this case Muwafiq explained:

\footnotetext{
43 Ibid.

${ }^{44}$ KH. Hasyim Muzadi, Nabdatul Ulama di Tengah Agenda Persoalan bangsa (Ciputat: PT Logos Wacana Ilmu, 1999), pp. 114-115

45 Muwafiq, "Gus Muwafiq Jelaskan.
} 
"We have our own folktales. In Nusantara we have Bawang Merah Bawang Putih. Europeans have Samson, Arabs have Sam 'un. We have Bandung Bondowoso, Sangkuriang, Si Pahit Lidah. Europeans have Romeo-Juliet, Arabs have Laela Majnun. We have Ande-Ande Lumut, they have a story like: Kura-Kura Ninja, we have a story: Kancil Nyuri Timun. Our language also cannot be disdained. The English say "rice" the Javanese say padi, gabah, beras, menir, lontong, ketupat, nasi, bubur, based on their shapes. Our language is also caste sensitive."46

Therefore, when questioning why the face of Islam in the archipelago is different from in other regions, of course the answer must be returned to how in its history Islam entered the archipelago. With this understanding, people will not easily look at or draw a different conclusion without first studying the background. In this case Muzadi explained that an understanding that lives in a certain generation never stood alone, but it is a repetition or a construction of thought from what has been built in the past. It could even be it is a refinement of what has been built in the past. ${ }^{47}$

It was in this civilized society that the Ulama began preaching Islamic teachings. They introduced Islamic teachings not only related to ritual methods, but also related to community and state concepts. Islamic terms and concepts related to state were introduced to the community such as musyarakah, ro iyah, musyawarah, majlis, kursi, wilayah and so on. With the intelligence of the Ulama, then those terms are absorbed and made the official language of the country. Muwafiq said:

"Then the Ulamas began to introduce a great concept about nation and state. They introduced the concept of how we live together looking after each other known as the term "musyarakab" which came to be known as "masyarakat" in Bahasa Indonesia which mean "society". If it has become a community, mutual understanding and responsibility then we are taught to adapt the Prophet's words "Kullukum ro`in wa kullukum mas'ulun 'an ro'iyyatibi". The term "king" and "servant" were removed and replaced by ro iyah. Which was absorbed into Bahasa Indonesia as rakyat meaning people. And the only Muslim Nation in the world

\footnotetext{
46 Ibid.

47 Muzadi, Nahdatul Ulama di Tengah Agenda Persoalan Bangsa.
} 
that is able to perfectly adapt the phrase ro iyah is only Indonesian scholars.48

Indonesian people have different characteristics compared to other nations in general. According to Muwafiq, the difference lies in the number of ethnic groups that must be protected by the Indonesian people. In other nations, generally one nation is shaded by many countries, but vice versa in Indonesia, one country houses many ethnic groups. In short, Indonesia is the choice of a country as referred to in the Qur'an Surat al Hujarat; 13: "therefore these diversities must be bound into a unity, that is by way of mutual respect for one another." Phrases or actions that can undermine the other must be eliminated and must instead be replaced by expressions that show togetherness, mutual tolerance and cooperation without having to question these differences. In this case Muwafiq explained:

So they must be united. There is no servant or king anymore, what exists is "ro “iyah" if they have already been ro "iyah, they may no longer call the infidels to the others, because infidels are against God and are hostile to Muslims, when they have lived together with us are called dzimmi. If they are all responsible for each other are called ro'iyah. Therefore, if they have been called ro iyah, they should no longer be called infidels in Indonesia." 49

These are Muwafiq's thoughts related to the efforts to maintain religious moderation in Indonesia. He is able to explain and provide a clear analysis of how Islamic teachings should be applied in Indonesia to a country full of diversity. He is able to contextualize the concepts of Islamic teaching with the reality in Indonesia, which make the teachings of Islam truly applicable in Indonesia towards a peaceful, tolerant and mutually respectful life.

From Muwafiq's speech as analyzed above, there are at least three main themes that are related to the idea of moderation; first, with regard to the concept of rabmatan li al alamin, second, about how the Prophet became an good exemplary figure in the da wa of Islam, third, with regard to the influence of tradition and culture in the implementation of Islamic teachings.

48 Muwafiq, "Gus Muwafiq Jelaskan.

49 Ibid. 


\section{Conclusion}

There are three important issues raised by Muwafiq regarding to efforts to maintain Islamic moderation in Indonesia. First, about the fact of diversity that is owned by the Indonesian people. This a Godgiven diversity cannot be denied. The efforts to find solutions of all the problems of the nation must depart for this reality, otherwise the nation that has been closely intertwined in diversity will be broken apart. Second, the Prophet Muhammad is seen as an exemplary figure who is able to be a role model in preaching, because he has successfully preached Islam in wise ways and is able to adapt his way of preaching to the conditions and character of society. The Prophet Muhammad 's ways to preach is important to be emulated by Muslims in Indonesia in the midst of efforts to maintain Islamic moderation. Third, in spreading the religion, the influence of traditions in Islamic teachings is difficult to avoid because in reality Islam comes to a society that has developed its own culture and tradition. This fact requires Muslims not to always think about how to eliminate the influence of local tradition in teaching Islam, but try how to make existing traditions in harmony with the values of Islamic teachings. []

\section{References}

\section{Books and Articles}

Amin, KH. Ma'ruf. "Khittah Islam Nusantara”. Kompas, 29 August 2015.

Azra, Azyumardi. Indonesia, Islam and Democracy: Dynamics in a Global Context. Singapore: Equinox Publishing, 2006.

Bhawono, Aryo. "Isu Separatisme Papua tak Akan Picu Konflik Indonesia Australia." https://news.detik.com/berita/d-3937373/isu-separatisme-papua-tak-akan-picu-konflik-indonesiaaustralia, accessed on 31 October 2019.

Chirzin, Muhammad. "Reaktualisasi Jihad fi Sabilillah dalam Konteks kekinian dan keindonesiaan". Ulumuna. 10, 1 (2006).

Darajat, Zakiya. "Muhammadiyah dan NU: Penjaga Moderatisme Islam di Indonesia". Hayula 1, 1 (January 2017).

Dhofier, Zamakhsari. Tradisi Pesantren; Studi tentang Pandangan Hidup Kyai. Jakarta: LP3ES 1994. 
Esaac, Farid, Qur an Literaty and Pluralism: an Islamic Perspective of Inter Religious Againts Opperssion. Oxford: Oneword Publication, 1997.

Al-Faruqi, Ismail R. and Lois Lamya al-Faruqi. The Cultural Atlas of Islam. New York: Macmillan Publishing Company, 1986.

Haedari, Amin et al. Masa Depan Pesantren dalam Tantangan Modernitas dan Tantangan Kompleksitas Global. Jakarta: IRD Press, 2004.

Hilmy, Masdar. "Whither Indonesia`s Islamic Moderatism? A Reexamination on the Moderate Vision of Muhammadiyah and NU". Journal of Indonesian Islam, 7, 1 (June 2013).

--------. Quo-Vadis Islam Moderat Indonesia? Menimbang Kembali Modernisme Nahdlatul Ulama dan Muhammadiyah, Miqot. XXXVI, 2 (July-December 2012).

Hornby, AS. Oxford Advanced Dictionary of Current English. Great Britain: Oxford University Press, 1987.

Karyadi, Fathurrahman. "Islam Nusantara dan Quraish Shihab". Abi Attabi". Antologi Islam Nusantara di Mata, Kyai, Habib, Santri dan Akademisi. Yogyakarta: Aswaja Pressindo, 2015.

Kementerian Agama RI. Moderasi Beragama. Jakarta Pusat: Badan Litbang dan Diklat Kementerian Agama RI, 2019.

Koentjaraningrat. Kebudayaan Jawa. Jakarta: Balai Pustaka, 1994.

Marijan, Kacung. Quo Vadis NU Setelah Kembali ke Khittab 1926. Jakarta: Erlangga, 1992.

Misrawi, Zuhairi. "Dialektika Islamisme, Khilafah, dan Syariat". Komaruddin Hidayat (ed), Kontroversi Khilafah: Islam, Negara, dan Pancasila. Bandung: Mizan, 2014.

--------. Hadratussyaikh Hasyim Asy ari Moderasi, Keutamaan dan Kebangsaan. Jakarta: PT. Kompas Media Nusantara, 2010.

Muhammad, KH. Husein. "Pesantren, NU dan Islam Nusantara". Abi Attabi . Antologi Islam Nusantara. Yogyakarta: Aswaja Pressindo, 2015.

Al Munawar, Said Agil Husin. Fiqh Hubungan Antar Agama. Jakarta: Ciputat Press, 2005.

Muwafiq, Ahmad. "Ceramah Muwafiq: KPK Ikhtiar Anti korupsi." https://www.youtube.com/watch?v=x7_Xq6zyKS0, accessed on 1 December 2019. 
"Live Muwafiq: Cara Paling Ampuh Menangkal Islam Radikal di Zaman Melenial." https://www.youtube.com/ watch?v $=$ P98hON2Ohgk, accessed on 1 December 2019.

."Muwafiq Jelaskan Al Fatikhah dan Kafir di Istana Bogor," https://www.youtube.com/watch?v=W11LQhgDPrs, accessed 1 November 2019.

."Muwafiq Singgung Habib Riziq dan Kafir di Gedung MPR RI," $\quad$ https://www.youtube.com/watch?v=zjh2M1eYI-I, accessed on 1 December 2019.

-. "Live Muwafiq di Unibraw: Tafsir Kontekstual Resolusi Jihad untuk Keilmuan dan Peradaban." https://www.youtube.com/watch?v=f2jyRF1g4Ew\&t=1943s, accessed on 1 December 2019.

Muzadi, KH. A. Hasyim. Nahdatul Ulama di Tengah Agenda Persoalan Bangsa. Ciputat: PT Logos Wacana Ilmu, 1999.

Nata, Abudin. Islam Rabmatan Lil Alamin sebagai Model Pendidikan Islam Memasuki Asean Community. http://abuddin.lec.uinjkt.ac.id/ articles/islam-rahmatan-lil-alamin-sebagai-model-pendidikanislam-memasuki-asean-community, accessed 27 November 2019.

Naufa KF, Ahmad, "Siapa Muwafiq? Ini 5 hal penting Kiai Berambut Gondrong." https://bangkitmedia.com/siapa-gus-muwafiq-ini5-hal-penting-kiai-berambut-gondrong/, accessed on 18 November 2019.

Sahal, Akhmad. "Kenapa Islam nusantarta?". Ahmad Sahal and Munawir Aziz (eds). Islam Nusantara dari Ushul Fiqh bingga Paham Kebanagsaan. Bandung: Mizan Pustaka, 2016.

Sobur, Alex. Analisa Text Media: Suatu Pengantar untuk. Analisa Wacana, Analisa Semiotik, dan Analisa Framing. Bandung: Rosda Karya, 2001.

Suharto, Toto. "Gagasan Pendidikan Muhammadiyah dan NU sebagai Potret Pendidikan Islam Moderat di Indonesia". Islamica 1, 1 (September 2014).

Syam, Nur, Merumuskan Islam Rahmatan Lil Alamin, http://nursyam.uinsby.ac.id/?p=514, accessed on 27 November 2019. 
Mohamad Salik

Umar, Nasaruddin, "Kisah Masjid nabi dan 7 ciri Islam Moderat." https://m.suara.com/wawancara/2016/06/20/070000/nazarud din-umar-kisah-masjid-nabi-dan-7-ciri-islam-moderat?page=all, accessed on 13 October 2019.

Zahro, Ahmad. Tradisi intelektual NU: Lajnah Bahtsul Masa il 1926-1999. Yogyakarta: LKiS, 2004. 